\title{
Wirehaired Pointing Griffon
}

National Cancer Institute

\section{Source}

National Cancer Institute. Wirehaired Pointing Griffon. NCI Thesaurus. Code C53874.

The Wirehaired Pointing Griffon is a rough-coated, medium-sized dog. It has a large, long head, square muzzle, and soft, thick, bushy eyebrows, beard and mustache. It has a straight, hard, wiry outer coat which is lined with a fine but thick downy undercoat. The coat comes in silver or steel-gray with chestnut or roam markings, or in solid chestnut. Height: 20-24 inches (50-60 cm.) Weight: 50-60 (23-27 kg.) 